A Plea for a Higher Standard for Entrance to Pharmacy, by C. B. Jordan. [Printed in this issue.]

Comparative Advantages of Practical Experience and General Education as a Prerequisite for Instruction in Schools of Pharmacy, by Dr. Rusby. [Printed in this issue.]

Dr. Anderson offered a resolution in approval of the Harrison Bill, which was adopted by the Section.

Adjourned.

\title{
ADDRESS OF THE CHAIRMAN.
}

If one but glance over Article I of the Constitution of this Association, he will conclude that the founders of the organization builded not for a clearing house of pharmacal thought, but for a militant organization resistant to the evils that then threatened, and now more direfully threaten, the calling, and active to overcome the lethargy in regard to educational, ethical, and professional standards, that hampers pharmacal progress. They hoped for a protagonistic organization, not an association of mere proclaimers. Quite well, along many lines, have their ideas been advanced, but the progress has not been what an active membership would have made it. Discussion there has been in plenty and some action too. That there has not been more action is no fault of the organization; there has been lacking among the individual members, that spirit, the lack of which differentiates the American from the citizen of other countries, that spirit of seeing to it that law-makers and law-officers take care of the law, of seeing to it that this board, or that body, performs its duties as they should be performed.

Have you, or have I, pointed out the short-comings of boards of pharmacy as servants of the law? Have we endeavored to rid pharmacy of the man who we knew full well was a detriment to the entire calling? Have you, or have I, raised any objection to the fraud perpetrated by the so-called "school of phar. macy" that graduates with a mark of 98 per cent. a young man who cannot write the full Latin name for epsom salt, or calculate the amount of a one-in-forty dilution of atropine sulphate required to make ten one-two-hundredth-grain dosages, or roll the corners off a pill? Have we not known the so-called "pharmacist" who would refill a prescription container from another pharmacy after smelling the receptacle and reading the label? Have we complained to the proper authorities concerning him? Have we exposed the druggist whom we knew was immorally, and perhaps illegally, selling narcotics? No; we have minded our own business-and let that business suffer from what really was neglect.

Along which of the two lines embraced within the purview of this section, education and legislation, we could achieve most for pharmacal advancement depends upon our bent and upon our environment. Legislation, to me, appears to be an over-exploited remedy for pharmacal ills. Education for pharmacists and for the public is of course a slower method of achievement and a method that requires constant attention; for public opinion, and pharmacal opinion as well. 
is evanescent--but education is a surer method; for, without education, legislation fails utterly.

There are so many problems in present-day pharmacy, that are being studied for solution along legislative lines, that they can merely be mentioned in an address that must necessarily be brief-a chairman, as I see it, should formulate and direct the program for his section, rather than occupy the greater portion of it. Others who will come before you will tell of the past year's endeavors to standardize all sorts of things from the shape of tablets of mercuric chloride to the graduations of nursing bottles. They will tell you how accroached rights and public welfare have clashed in the struggle against the drug evil; how the medicine pedler has practiced pharmacy, and the dispensing doctor has been above the law, a law apparently enacted for the protection of the public, but more evidently for the restriction of the pharmacist. When they have told you these things, de you, I pray, read the first article in your constitution and enlist in the endeavors that it purposes?

L.et me call your attention to some educational needs of pharmacy; there are but two important among these. One important need is education; the other is educators. The need for education is two-fold. The pharmacist should be an educated man and the man in pharmacy should be an educated pharmacist Slowly but surely there is dawning in general educational circles the light whose rays were first focalized by Froebel, the light that shows that to do is to know; and sense-training is fast taking the place of memory-cramming in educational methods. Glad will be the day when this light illumines pharmacal education when the pharmacy student's thoughts are directed toward the real purpose of instruction, the imparting of that knowledge that constitutes education, and away from the examination at the end of the semester or the tests by the board of pharmacy; when he comes to look upon instruction as a means toward an end and not as an end in itself.

The prelininary education that the pharmacy student should have, has been standardized to a certain extent, but apparently it has been standardized for the sake of standardization rather than for the purpose of getting an educated pharmacist. Mathematics, physical science, introductory chemistry, logic-these are necessary in the foundation of any professional education. They are usually conspicuously absent from among the counts upon which the pharmacy student cer. tificate is granted. None can be of service to pharmacy who is but crammed witr learning and has not the initiative that is the first characteristic of education. Look over a lot of theses prepared by candidates for a degree in pharmacy, even for the doctorate: What initiative, what originality, do they indicate? The faul1 is not all in the teaching of pharmacy; much of it lies farther back in the educational life of the student; and pharmacal instruction has a difficult task in building a trained professional man upon no other foundation than a crammed memory

That there is a lack of efficient pharmacal educators is evident to any one who has any knowledge of educational methods and educational results. It is not enough that a man be an authority in his subject, to make him an efficient instructor of others. If he has not a thorough knowledge of human nature and at least a fair grasp of the psychology of imparting and receiving instruction, he 
cannot instruct. The real teacher can tell through observation of the faces before him-he needs not wait for the examination to determine it-which, among his students, are memorizers, which miss the point of the instruction entirely, and which catch and fix the idea independent of the words in which it is expressed. There is a need for trained educators in pharmacy and this Association should endeavor to remedy it.

Few of us have not heard criticism of the apparent divergence of the lines along which schools of pharmacy and boards of pharmacy, determine the fitness of practitioners of pharmacy. That there is a divergence is evidenced by some statistics collected by my associate, Mr. R. A. Kuever, which show that of 1,497 graduates of pharmacy schools, examined recently by seventeen boards of pharmacy, only 65.06 per cent. were passed. Can we say, therefore, that the schools of pharmacy are not doing their duty? Is it, on the other hand, that the boards of pharmacy are poor judges of pharmacal fitness? This is a question that this Association might well take under consideration. Some other figures collected by Mr. Kuever are interesting in this connection. He found that thirty boards of pharmacy examined five thousand three hundred and ninety-three applicants for registration in a given period and passed 54.55 per cent. Twelve of these boards had examined graduates, so-called, of short-course, or cramming, schools, to the number of three hundred and ninety-one. Of these 49.36 per cent. were passed. Evidently the regular school of pharmacy is a little better judge of pharmacal fitness (on a board standard) than is the cramming school. As far as Mr. Kuever was able to ascertain, there are twelve of these cramming schools that are well known: this number does not include the correspondence-course institutions. These cramming schools are without standards; but they get half their students past the board, - and to pass the board is the chief desire of by far the greater number of pharmacy students.

There are many legislative problems upon which the chairman might base recommendations to this section, but I prefer to leave these to the several com. mittees and delegations that have to do with legislative matters. Let me, however, suggest that you take an active part in the attempts to restrict the traffic in narcotics to moral lines, paying particular attention to the necessity for the restriction of physicians and especially veterinarians who are not amenable to very stringent laws of any sort; that you do not overlook the present-day opportunity to achieve a much-desired reform in our patent laws relative to medicinal products; that you leave not to the civic organizations the survey and regulation of the practice of pharmacy; that you coöperate in the conservation of real pharmacy; that you, in short, become protagonists for the purposes set forth in Article I of the Constitution of the American Pharmaceutical Association.

In the educational field, I would recommend: (1) That this Association create a committee to survey pharmacal educational methods.

(2) That this Association take steps toward the supplying of efficient pharmacal educators trained along pedagogic, as well as pharmacal, lines.

(3) That this Association interest itself in the modern movement toward the concrete and practical in general educational practices.

(4) That this Association concern itself with the coördination of the methods 
of schools of pharmacy and boards of pharmacy, particularly that practical pharmacy may be conserved.

(5) That this Association take steps toward securing the better enforcement of the statutory provisions that safe-guard the practice of pharmacy.

As a topic for discussion at the meetings of state pharmacal organizations next year, I suggest this:- "Should the Ownership of a Pharmacy be Restricted to a Registered Pharmacist?"

Respectfully submitted,

Hugh Craig,

Chairman.

REPORT OF COMMITTEE ON CHAIRMAN'S ADDRESS.

Your committee, to whom was referred the address of Chairman Craig, takes this opportunity to express its appreciation of the excellence of the address, its admiration of the sentiments therein contained and its concurrence with the suggestion offered for the improvement of pharmaceutical education and legislation.

We endorse the recommendation that the Association use its best efforts to secure such restrictions of the traffic in narcotics that shall include all who are responsible for the abuses in the dispensing or sale of narcotics.

We endorse also the recommendation relative to the reform of our patent laws concerning medicinal products; likewise, the suggestion that pharmacists themselves should undertake the survey and secure the regulation of pharmacal practice, and not leave these vital matters to organizations which are non-pharmacal in character.

We believe that the survey of educational methods mentioned by our chairman should be carefully considered by this section, and, that a committee should be appointed to report a plan of classifying all the various institutions now engaged in giving instruction in pharmacy in this country.

We advise that the recommendation of our chairman concerning the coördination of the methods of schools and boards of pharmacy be made a subject for discussion and action at the joint scssion of schools and boards with this section and to the same joint session we would refer the recommendation that steps be taken to secure the enforcement of the statutory provisions that regulate the practice of pharmacy.

We approve of the chairman's suggestion of submitting a topic for discussion at the meetings of state pharmaceutical associations next year, and, we recommend that the secretary of this section communicate this suggestion to the secretaries of the various state pharmaceutical associations.

W. B. DAY,

M. I. WILBERT,

E. A. Ruddiman. 